\title{
Alpha Children Wear Grey: Postwar Ontario and Soviet Education Reform
}

\section{Josh Cole}

A map of the world that does not contain Utopia is not even worth glancing at, for it leaves out the one country at which Humanity is always landing.

—Oscar Wilde, "The Soul of Man Under Socialism”

\begin{abstract}
In this study, the author examines a prominent Ontario education commission's tour through the Soviet Union in 1966. This tour is situated within the larger contexts of the Cold War, and postwar North American education reform. Using the commission's unpublished tour report on the U.S.S.R., and the theoretical tools of utopia and dystopia, contradictions within the commission's response to Soviet education are explored and then linked to deeper tensions in its views on education and its ideological role in postwar Ontario society.
\end{abstract}

RÉSUMÉ

Cette étude a pour cadre une tournée en Union soviétique organisée en 1966 par les membres d'une importante commission ontarienne sur l'éducation. Deux éléments caractérisent cette visite : le contexte de la guerre froide et celui de la réforme de l'éducation nord-américaine durant cette période. À partir du rapport inédit de la commission sur sa tournée en URSS et des approches théoriques de l'utopie et la dystopie, l'auteur analyse les réactions contradictoires de la commission face à l'éducation soviétique. Ces oppositions sont en fait révélatrices des points de vue divergents de ses membres et du rôle idéologique de l'éducation dans la société ontarienne d'après-guerre.

The authors of the Ontario government's 1968 report on education reform, Living and Learning (also known as the "Hall-Dennis Report") would surely have agreed with Wilde's assessment. Over the three years the "Hall-Dennis Committee" spent exploring contemporary educational thought and practice, they commissioned material from expert researchers, solicited contributions from various groups interested in 
the future of Ontario education, and conducted hearings to ensure their ideas were informed by public opinion. They also travelled widely, chasing better pedagogical worlds in the form of cutting-edge educational experiments in Ontario, Eastern and Western Canada, the United States, Europe, Asia, and the Middle East. Their most unorthodox trip took them to the Soviet Union. What they found there was a dystopia that challenged their own liberal-democratic sensibilities in important ways, yet proved surprisingly compatible with them in other respects. The tour report they produced afterward, entitled "Education in the U.S.S.R.," offers considerable insight into the Hall-Dennis Committee's vexed response to this ideologically alien terrain, as well as their own developing ideas on education's role in the postwar Ontario state. ${ }^{1}$

In late-1964, Bill Davis, Ontario's minister of education, concluded that the province's curriculum needed to be overhauled. For him, the world of the mid-1960s looked vastly different from that of the 1950 s, when the last comparable examination - the so-called "Hope Commission" of 1950 — had been undertaken. To this end, he struck a committee to examine the educational system, and bring it up to speed with the postwar 'modern' world. According to the committee's terms of reference, it would "identify the needs of the child as a person and as a member of society," "set forth the aims of education for the educational system of the Province," "outline objectives of the curriculum for children in the age groups presently designated as Kindergarten, Primary and Junior Divisions," "propose means by which these aims and objectives may be achieved," and finally "submit a report for the consideration of the Minister of Education." 2

The committee was designed to be democratic. It drew its members from several sectors of Ontario society. It included teachers, teacher educators, a businessman, a farmer, a union representative, an accountant, and a homemaker/school-trustee. It was chaired by Emmett Hall, a Supreme Court of Canada judge fresh from heading up the Royal Commission on Health Services, and Lloyd Dennis, an ex-primary school principal. ${ }^{3}$ Hall convinced Davis to expand the mandate to include all schooling in the province, from pre-school to grade thirteen (a bid to include tertiary education was rejected). The committee then began grappling with difficult, not to say perennial, questions. These included: what is the nature of the child as a learner? What should be the respective roles of teachers, students, and school officials in the educational process? How should schools make use of new means of communication? What is the proper relationship between the educational system and business? How should schools respond to 'Canadian Indian' children? To the 'culturally deprived'? To new Canadians? What should be the role of marks and examinations in education? What balance should be struck between classroom discipline and the freedom of the child? Their proposed answers seemingly threw much of the existing system into doubt. The committee's key conclusion was that education must revolve around each individual student's unique learning experience in relation to the dynamic world of the later - twentieth century. ${ }^{4}$

Their report - its full title was Living and Learning: The Report of the Provincial Committee on Aims and Objectives of Education in the Schools of Ontario-was presented to Davis on 12 June, 1968. It bore little resemblance to a traditional 
governmental report. Neither dull nor grey, it announced its distinctiveness in a brightly coloured cover, which depicted youngsters running through a lush meadow. It contained copious pictures of youth hanging out in the modern cityscapes of urban Ontario, as well as full-colour, multi-page examples of children's art. With pop art and psychedelic influences evident in its typography and design, the report was as progressive in form as it was in content. It was plainly designed to reflect, and ultimately to affect, the times that produced it. Politicians across the ideological spectrum embraced it. Toronto's Globe and Mail newspaper devoted eight pages to it the day after its release, proclaiming that: "Judge Emmett Hall and his crew have set education on its ear, exposed the failures of every educational institution in the province, plunged eagerly and creatively into the future, and undoubtedly occasioned the eruption of fountains of cold sweat throughout the educational establishment."5 The public responded as well. It sold some 60,000 copies within sixteen months of its publication. ${ }^{6}$

Historians of Hall-Dennis have generally allowed the committee's international tours to pass without comment. Only the social and cultural historian, David Churchill, has touched on Living and Learning's international dimension. He argues that Hall-Dennis sought to articulate the local with the international, linking Toronto experimental schooling to global developments in education. As he writes, the committee "explicitly rejected nationalistic curriculum in favour of more universal principles that linked educational reforms throughout Europe, the United States, Canada, and other western nations." 7

Though its tour destinations were novel, the committee was following a well-worn path in looking abroad for educational reform inspiration. As Daniel T. Rodgers writes in his now-classic Atlantic Crossings: Social Politics in a Progressive Age, "Even the most isolated of nation-states is a semi-permeable container, washed over by forces originating far beyond its shores." ${ }^{8}$ Nowhere is this more apparent than in education, as the historical sociologist Bruce Curtis asserts: "As soon as one begins to trace networks of contact, acquaintance and influence in the educational field, it quickly becomes obvious that everyone was connected to everyone else." 9 This is, of course, eminently logical. Much time, energy, and expense can be saved by looking toward other educational systems, rather than engaging in haphazard and costly trial and error at home. By looking outward, policy makers could find a ready-made "abundance of solutions." 10

In the case of post-1945 Canada, this was truer than ever. During this period, participation in international educational exchanges and conferences became common, organizations such as the Canadian Association for Adult Education became world leaders in their field, metaphors of the "global village" became ubiquitous in pedagogical discourse, and several provinces offered international educational aid to so-called 'developing countries.' ${ }^{11}$ Ontario was particularly involved in this last venture. For instance, in 1966, Davis launched what he called "Operation School Supplies." Though this program, educational materials were transported — "approximately 1,000 desks and three tonnes of textbooks" — to the Bahamas, via Hercules aircraft borrowed from the Canadian military. Davis told the province's legislature 
that he considered these materials "weapons of the mind." 12

These martial connotations befitted postwar education's Cold War context - in Ontario and around the world. The Cold War immediately followed the Second World War, and saw a multitude of conflicts frozen into just one: that between the United States of America and the Soviet Union. The Cold War never became 'hot.' Instead, it was fought out through proxy wars and immense propaganda campaigns in which both sides sought to convince a global audience that theirs was the superior social and economic system. For the countries aligned with the U.S.S.R., that system was communism. For those led by the U.S.A., it was liberal-democratic capitalism. ${ }^{13}$ Yet, in a crucial sense, the real audiences were domestic. From 1945 to the later1980s, when the Cold War drew to a close, those on either side of the divide sought to convince their own populations that if their values were not upheld, and the others "contained," Third World War would inevitably result. ${ }^{14}$

Education played a crucial role in the Cold War. In the United States after 1945, many close to the centre of power became convinced that the Soviet worldview would inexorably draw them towards global domination. Those who were skeptical became less so after the U.S.S.R. sealed off East Berlin, exploded an atomic bomb, and Communist revolutionaries took over mainland China. ${ }^{15} \mathrm{~A}$ consensus then developed that the war effort would have to transcend traditional military action. With Dwight Eisenhower's two presidential terms, education came to the fore. The former Supreme Allied Commander was well aware of the role that science and technology played in winning the Second World War, and was determined to use such "brainpower" in the Cold War. By the 1950s, the Central Intelligence Agency began producing information suggesting that the U.S.S.R. was outpacing the U.S. in science, technology, and science pedagogy. The publication of the National Science Foundation's (NSF) report, Soviet Professional Manpower in 1955 buttressed this notion of an 'education gap' between East and West. Further, the NSF argued that science in the postwar U.S.S.R. flourished in an atmosphere of free-inquiry, uninhibited by ideological constrictions. This made the advance of Soviet science and technology potentially limitless. ${ }^{16}$ After the U.S.S.R. exploded a hydrogen bomb, and launched the first Sputnik satellite into orbit in 1957, education and defense policy became inextricably intertwined. ${ }^{17}$

Canada was a major American ally in the Cold War. After 1945, it participated in the U.S.-led Marshall Plan for re-creating the shattered economies of Europe, it joined the North Atlantic Treaty Organization (or NATO), and by the 1950s, it was a full partner in a continental air defense system (North American Aerospace Defense Command, or NORAD). It also fought alongside the U.S. in the Korean War. ${ }^{18}$ That said, fissures in the relationship began to develop by the early-1960s. Never anything like an equal partner, Canada was kept out of negotiations between the U.S. and the U.S.S.R. during the Cuban Missile Crisis. As a result, as Reg Whitaker and Steve Hewitt argue, the Canadian public began to sour on a situation in which the American and Soviet leadership seemed "accountable to no one but themselves." After this point, looking for social and political alternatives outside of the U.S. orbit became more acceptable in Canada, and would only become more frequent as the 1960 s wore on. ${ }^{19}$ 
This search for alternatives took hold early on in the field of education. By the 1960s, the Cold-War anxieties of Hilda Neatby's 1953 bestseller, So Little for the Mind gave way to more nuanced approaches to Canadian education's place in the international order. ${ }^{20}$ For instance, as curriculum historian George Tomkins points out, Design for Learning (1962), a report drawn up by a joint committee of University of Toronto faculty members and the members of the Toronto Board of Education (including future Hall-Dennis co-chair, Lloyd Dennis), argued that Ontario and Canada should chart their own educational paths, outside of the Cold War context. ${ }^{21}$ In the introduction, the literary and cultural critic Northrop Frye wrote that "The kind of vague panic which urges the study of science and foreign languages in order to get to the moon or to uncommitted nations ahead of the Communists is ... remote from the educational issues that these reports face. Human nature being what it is, serious educators would probably not have got as much public support for their efforts without headlines about sputniks, but they could see the facts of the situation without such headlines." 22

It was within this more open atmosphere that Dennis could, two years later, successfully argue to Ontario's Department of Education that it would be "presumptuous" of Hall-Dennis to make "significant recommendations for change without also examining related educational exercises now prevalent in systems other than Ontario's." Further, he could assert that the Soviet Union would be an ideal destination in which to examine kindergartens, vocational training, educational research, and other issues. This would have been a harder sell during the 1950s. And, though a member of the Department asked him if the province was really going to send HallDennis to "Russia," the trip proceeded all the same. ${ }^{23}$

The theoretical tools of utopia and dystopia can be used to throw light on HallDennis' interpretation of Soviet education. The term "utopia" was coined in 1516 by the English lawyer, politician, and philosopher, Thomas More in his Concerning the Best State of a Commonwealth and the New Island of Utopia. ${ }^{24}$ Derived from the Ancient Greek, it can mean either "no place, or "good place." Thus, it commonly signifies a "non-existent good place." ${ }^{25}$ A more recent definition has it as "an elaborate vision of 'the good life' in a perfect society which is viewed as an integrated totality." ${ }^{26}$ While utopianism is most commonly found within the cultural sphere, it has its place outside of it as well. Many modern social experiments have been utopian in nature: from the French Revolution of the eighteenth century, to the founding of the alternative community of Harmony, Pennsylvania in the nineteenth, to the Kibbutzim movement in the early-twentieth. What all utopias have in common, as the sociologist Zygmunt Bauman points out, is that they start with the real world and its shortcomings - a "field of the possible in which the real occupies merely a tiny plot" - and then transcend it in the hope of building a better world. ${ }^{27}$

Education is a key component of utopian thought and practice. The high place accorded to education in utopianism is due to the foundational role that imagination plays in all utopian plans, as well as the fact that many utopians were (and are) educators themselves. ${ }^{28}$ As Michael A. Peters and John Freeman-Moir put it, "utopias can be thought of as fundamentally educational in the sense that they are 'designs' 
for living — modes of urban and rural planning, technology, work and leisure - designed explicitly for encouraging the development of certain kinds of habits, dispositions and attitudes." ${ }^{29}$ In More's Utopia, for instance, education served as the primary means by which a perfected society maintained and perpetuated itself - inside the school, as well as "at home, at church, in public, and at work." ${ }^{30}$ In Utopia, citizens were infused with the notion that "the contemplation of truth begets true delight," and that "Literature is the object of love because it is the source of great pleasure." ${ }^{31}$ Utopianism thus involves a nearly biopolitical 'education of desire' in which "strict obedience and freedom coincide." 32

Utopianism is often (and correctly) associated with totalitarianism, but it winds its way through the history of liberalism as well. Though many would insist that a liberal society is one in which utopian social and economic planning is anathema, a more critical approach reveals that social relations and practices in liberal societies are constantly designed and re-designed in order to allow liberalism to flourish as a set of ideas. ${ }^{33}$ Liberal intervention may not be overt, but it is no less real for that. As Bruce Curtis suggests, a world that is "opaque, contradictory, confused, or illegible," and "not conducive to rational comprehension" is one in which liberalism cannot take root. ${ }^{34}$ Thus, this world must be re-made through the work of 'organic' liberal intellectuals through legal reform, the construction of new social and economic institutions (the postwar 'welfare state,' for instance), and coercive force, as well as innumerable smaller transformations in currency, scientific measurement, pedagogy, and school curricula. Through means such as these, liberal subjects are educated in the broadest sense, learning to "read, write, cipher, plan" as well as "defer to those most rational in society." ${ }^{35}$ In short, liberalism is less an empirical response to a 'natural world' already existing, than an immersion in a consciously created, 'social dream,' that conditions and empowers liberal subjectivities. The system of ideas reflecting and reinforcing such arraignments is, to a greater or lesser extent, 'agent-neutral,' universalized, and ahistorical. As the philosopher John Gray argues, this particular form of liberalism successfully crowded out other, more anthropologically-grounded alternatives after 1945. ${ }^{36}$ Liberalism strips away old selves, and "clothes" its subjects anew, just as utopianism does. ${ }^{37}$

Utopias do not just map out possible futures. They also tell us much about their creator's relation to their own, present social situation: what is broken, and how it might be fixed. ${ }^{38}$ North America after 1945 was shot through with utopian hope (and dystopian fear). The postwar North American social and cultural fabric was built upon the desire of governments, intellectuals, and the general public to transcend war and economic depression, in order to forge a better world (in this respect, the advent of the United Nations is the paradigmatic postwar utopian achievement). ${ }^{39}$ After 1945 , the possibility of such transcendence was driven by an ideology of 'progress' seemingly borne out through the 'knowledge explosion,' the global village of mass communications, dynamic technological change, and the 'Golden Age' of economic growth. ${ }^{40}$ [period missing]For the "best fed, best-educated, and healthiest generation in Canadian history" ideas of freedom, abundance, and 'modernity' became hegemonic. ${ }^{41}$ Postwar educational rhetoric reflects this clearly, as plans proliferated for 
"futuristic schools" in which "humanity's rich collection of symbol systems" would be accessible to all children equally. ${ }^{42}$

Finally, recent scholarship has drawn attention to the connections between utopia and dystopia. They are commonly thought of as opposites, but as historians Michael D. Gordin, Helen Tilley, and Gyan Prakash argue, their relationship is more complex than this. A dystopia is not a simple inversion of a utopia. It is not a 'bad place' to utopia's 'good place.' Rather, dystopias are utopias "gone wrong." They are rationally planned to be utopian, but are societies in which those plans are found to be defective. ${ }^{43}$ Thus, both utopia and dystopia have to be considered twinned phenomena-one successful, the other failed: "two imaginaries, the dream and the nightmare." The true converse of both is a third position: chaos - not a utopia, or a dystopia, but rather a society without structure - a "completely unplanned" society. ${ }^{44}$

It was from a utopian standpoint that the Hall-Dennis committee embarked on its research journeys - voyages to distant lands, in search of better worlds - in the hope of fixing what they considered broken in postwar Ontario. This utopian drive endured throughout its work. As the committee wrote in 1968's Living and Learning: "The underlying aim of education is to further man's unending search for truth ... This is the key to open all doors. It is the instrument which will break the shackles of ignorance, of doubt, and of frustration; that will take all who respond to its call out of their poverty, their slums, and their despair [making] all men brothers, equal in dignity." 45

What Hall-Dennis found when it arrived in the Soviet Union — or at least what it reported finding in "Education in the U.S.S.R." — was a utopian social and educational system, that on closer inspection, revealed complex dystopian underpinnings.

As American intelligence suspected, postwar Soviet education did indeed prize "technology, science, and mathematics - the fruits of man's efforts to understand and control the forces of nature," as the American educational theorist, George Counts put it in $1957 . .^{46}$ And, they did attempt to use educational policy to mould a "technologically sophisticated, skilled, and ideologically imbued population" to further their Cold War aims. ${ }^{47}$ Yet, the genealogy of Soviet education contains more twists and turns than this. By the time Hall-Dennis arrived in 1966, Soviet education had already moved through several phases. When the Communists took control of Russia in 1917 , they immediately elevated an existing cadre of progressive educators to positions of prominence in the new state apparatus. These intellectuals were part of "a community of progressive thinkers crossing not only the Atlantic Ocean but also the Baltic Sea." They were inspired not by Marx, but by Russians like Leo Tolstoy, and Americans such as John Dewey. ${ }^{48}$ In their pre-revolutionary experiments, and then again as post-revolutionary cultural workers, they sought to close the gap between schools and Russian life. ${ }^{49}$ The Soviet educational goal in this era was free, compulsory, co-educational, progressive schooling, "combining vocational and academic education without regard to the class origins of the pupils." 50

Cultural exchanges between the new Soviet state and the capitalist countries then began to multiply. The 1920s and 1930s saw "the cream of the interwar cultural and intellectual elite, as well as thousands more rank-and-file experts, progressives, public 
figures, and many others" flooding into the U.S.S.R. to glean insights for improving their own societies - particularly following the crisis of the Great Depression. ${ }^{51}$ These travellers saw the U.S.S.R. as a potential field of utopian possibilities for improving the state of the capitalist west, currently buckling under the weight of its own contradictions. The Soviets, in turn, garnered information, technical expertise, and political legitimacy from these visitors. ${ }^{52}$ One of them was Dewey himself, who made the trip in 1928. He was immediately taken with the progressive nature of Soviet schooling, and their adoption of his own ideas as well. Once back in the United States, he began proselytizing for a version of this educative society in North America. This earned him many detractors, who branded him a communist sympathizer. ${ }^{53}$

This golden age of Soviet education was grinding to a halt by the time Dewey made his journey. This was due to resistance from traditional teachers, a lack of material resources for the new system, and political pressures - particularly as earlier progressives were replaced by more hard-line Marxists. These new educators called not for a dialectic between school and life, but rather for life alone, minus the school. Education now centred on activities such as collective farming, and lessons on "Lenin," "Our Agricultural Soviet," and "Industry in Our Region." ${ }^{44}$ It was only with the death of Stalin in 1953, and Nikita Khrushchev's rise to power, that education in the U.S.S.R. assumed its postwar shape. Khrushchev's Soviet Union dedicated itself to economic growth and power through "education, rocketry, and science." 55 By the later-1950s, children attended an elementary school that combined basic academic and vocational study, before a more technical training phase, or entrance into elite "magnet" schools focussing on mathematics, language, and the arts. ${ }^{56}$ After the shock of Sputnik, the U.S.S.R. once again gained an international reputation for education and school reform. It was this incarnation of Soviet education that Hall-Dennis encountered in 1966.

The committee members who visited the U.S.S.R. — the psychologist, Reva Gerstein; the former President of the Women Teachers Association of Ontario, Ola Reith; and E.J. Quick, the committee's secretary and research director — immediately responded to the utopian aspects of Soviet education. First and perhaps foremost, they were deeply impressed by the Soviet state's deep devotion to educational planning. As they reported, the importance the Soviets attributed to education as a social investment far outstripped that of any other country the committee visited. Further, the U.S.S.R. was bursting with confidence about what education could do for them in the future. The opening of their report is worth quoting at length on this score:

Education holds a position in the Soviet Union that is unique among the countries of the world. Lenin, the father of Russian communism, was an intellectual and he stressed the importance of a high level of public education. A picture or bust of Lenin appears in almost every classroom or school hallway in Moscow and Leningrad ... Following the educational precepts of Lenin, the Russians almost eliminated illiteracy in twenty years, and the crowning achievement of their educational system was putting the first satellite into orbit. Now they are challenging the greatest industrial nation in the race to the moon. The people 
of the Soviet Union almost worship their scientists. No one questions the importance of education or the percentage of the nation's resources being devoted to it. The people have made great sacrifices for education and the development of heavy industry. Their material standard of living seems to be thirty years behind Canada's, but through education and the Communist state they expect to achieve the highest standard in the world. The Communist philosophy of dialectical materialism will have failed if they do not do so. ${ }^{57}$

Hall-Dennis also conveyed its admiration for the massive educational research and development facilities that had sprung up in the postwar Soviet Union. The delegation was informed by its guides that these were only "growing in numbers and importance." ${ }^{58}$ There, Soviet pedagogues did "advanced research," spread "educational information among the general public," and used these centres "as a general clearing house for educational studies and discussion." The director of the Institute of General and Polytechnical Training of the Academy of Pedagogical Science in Moscow informed the committee that they were currently investigating ways to reform education in order to teach children more at ever younger ages. He asserted that the "curriculum now teaches as much in the first three years as was formerly taught in four years. This enables the students to cover the same material in 10 years as had been formerly taken in 11 years." 59 These techniques were then tested in "laboratory schools" overseen by "university specialists, the pedagogical experts, and talented teachers." Hall-Dennis was privy to one of these classes, investigating what the Institute referred to as "new approach mathematics." There, they saw "gifted children" presenting their "theses" to fellow students and instructors. ${ }^{60}$ This approach resembled progressive child-centered discovery learning as well as Jerome Bruner's "Structure of the Disciplines" theory, then making waves in schools across North America - approaches that Hall-Dennis favoured throughout its educational investigations. ${ }^{61}$

In addition to this, these laboratory schools were filled with educational technology. Over the course of their research, this also was as a key signifier of pedagogical modernity for Hall-Dennis. These classrooms - and their computers in particular — had the committee "delightfully sidetracked," as they toured the facilities. ${ }^{62}$ They were told that this technology would soon be used in all secondary schools in the U.S.S.R. - bringing "the content and character of secondary school education into conformity with the modern level of scientific, technical, and cultural development." The head of the Institute also claimed it would attune teaching to the individual "pupils' abilities and wishes." ${ }^{3} \mathrm{He}$ added he that had been to Ontario, and had not been impressed by what he saw. As he had it, science education in the province was far too traditional, because it was not taught by professional scientists. As a result, he asserted that Ontario would soon lag behind more advanced systems such as the Soviet Union's. ${ }^{64}$

The committee also visited public schools in Moscow and Leningrad. In Moscow, an English class they observed featured an "excellent lesson using a tape recorder, earphones, etc." The atmosphere seemed open, relaxed, and productive, featuring "free interaction between the teacher and pupils and among the pupils themselves 
during an imaginary telephone conversation in English." This was followed by "a contest at the blackboard to write a story in English that was being played on the tape recorder." The students also incorporated information about Canada into the lesson. As they wrote: "Pupils popped up and bombarded questions. A choir sang 'Little Polka Dot Bikini;' 'White Coral Bells;' and This Land is My Land'. They laughed and jostled in the halls, followed members of the delegation, and questioned them about hair styles in Canada." ${ }^{65}$ This heady combination of educational planning and investment, progressive pedagogy, devotion to technology, and student engagement pushed the U.S.S.R. in Hall-Dennis' eyes from being merely innovative, into the realm of the utopian.

Despite how impressed they were with what they had seen, the committee members had reservations as well - and, as is often the case with utopias, dystopian aspects soon began to surface. After visiting the Moscow school, they wrote that it would have to be offset with another "to show the danger of generalizing from too few examples." In the Leningrad public school, they noted that the principal was disorganized, constantly rushing "from room to room throughout the school." The computers that had so impressed the committee in Moscow were unused, gathering dust in a storage room. More importantly, the atmosphere of freedom they witnessed earlier was absent. It was replaced by what the committee took to be a stiff, traditionalist pedagogical approach. One group of students "gave a formal recitation of a poem in English which they had memorized, English accent and all." The committee added that: "In the auditorium the principal had a boy recite a passage from Shakespeare. He looked at the ceiling, the window, and the floor...It was painful to watch!" Overall, this performance seemed as artificial as the Moscow display was joyous. Before the principal rushed the students off to the next class, she enquired whether they would like to ask Hall-Dennis any questions. The committee reported that, "as can be expected, there was not one question." 66

More disturbing still was the blatantly anti-individualist thrust of some schools they visited. The kindergartens they observed in Moscow and Leningrad stressed "exercise, fresh air, rest, a balanced diet and medical attention." They featured special educational programs, free of charge and open to all citizens. Yet, as the committee reported, they also preached the subordination of the child to the larger goals of Soviet society - what the committee described as "mutual activities in the collective." ${ }^{67}$ As they wrote:

The delegation's intourist guide had a three-year-old daughter who had just started kindergarten. It was interesting to watch the maternal anxieties of a Russian mother. Her daughter was precocious, and was having difficulty adjusting to the group life of the kindergarten. When it was suggested to the guide that the school should adapt the program to her daughter's special needs, she agreed at first, saying that she had taught her daughter to read during the previous summer - and the school should give her special work - then all at once she stopped, as if she had a pang of conscience, and said "no, she must fit into the collective." 68 
By the time Hall-Dennis arrived at its "general conclusions," its judgement on Soviet education was overwhelmingly negative. The utopian character of Soviet schooling was revealed to be fundamentally and definitively flawed. Lenin, the admired intellectual of the report's opening, was transformed into a menacing figure, commanding students from busts in school hallways to "Learn, learn, and learn." Education now had a single, ominous goal: "the moral and ethical development of the future citizens of the communist state." In school, children and young people would learn that the "individual's role is to serve the state. He serves the state best by being well-educated ... Knowledge is virtue. Knowledge is power." Further, they asserted that this knowledge would be drilled into the minds of children and young people through the mechanistic psychology of Ivan Pavlov, with its "emphasis on sensory conditioning." ${ }^{69}$ While math, science, and engineering were obviously valued in Soviet schools, less utilitarian subjects were ignored, because "they were not useful." The committee argued that this inattention to culture signified a society in decline, not ascent. This could be seen not only in Soviet education, but in all aspects of cultural life. As they wrote: "Although traditionally Russian opera and ballet have been excellent, they have become stylized. Touring companies are being criticised for their lack of originality and creativeness." The built environment came in for similar critique: "The architecture of buildings lacked creative imagination, and there was a dull uniformity of urban economy." They ended by taking stock of Sweden — which they had visited previously - in comparison to the U.S.S.R. "In Sweden, the people had come to terms with themselves. As a small country, they have decided to become world citizens and peacemakers. Within this framework they encourage individual interests and excellence." By contrast, the Soviet Union "considers itself a world power" that cares for little except that which gears them for "power and strength."70

Yet, this was not all. Appended to "Education in the U.S.S.R." was a three-page coda, in which Hall-Dennis praised the work of a single Soviet educator: Anton Semenovych Makarenko. It is here that the thin line between utopia and dystopia was thrown into sharpest relief in relation to Hall-Dennis' journey to the U.S.S.R.

Makarenko was famous within the Soviet Union by the 1960 s, yet virtually unknown outside of it. ${ }^{71}$ That fame rested on his work during the 1920 s with children orphaned during the First World War. According to his proponents, he solved a fundamental dilemma in early Soviet education: how to recognize individual freedom, while ensuring the "continued development of the socialist school and the emergence of the socialist society." $72 \mathrm{He}$ did this by cultivating a "solidarity of interest" among unruly children and young people. To this end, he employed extreme measures, including violence and the "liberal use of threats to expel those who failed to conform to requirements." 73 All of this was geared toward the creation of "the ideal future society." 74

The committee's approval of Makarenko was absolute. It argued that he was "the essential quarry in Marxist education," and that if there was "any content to Marxist educational theory, this may be attributed almost to him alone." It heartily approved of his methods for instilling "common standards of behaviour," "a common will to action," and "a consciousness of community." This, in turn, could not 
be accomplished through mere "talk," or "within the artificial classroom situation." Instead, this "collective will" would have to be forged through labour, overseen by a powerful, even domineering teacher-figure. What mattered above all else, was discipline: without it, "no satisfactory communal action is possible." Once the student's "anarchic individualism" was overcome, he or she would emerge as a fully-formed citizen, yoked to the social whole. Such an approach seemed to clash completely with the committee's oft-stated dedication to individualism and liberal freedom - as well as its own (eventual) denunciation of what was observed in the U.S.S.R. Why was this figure singled out and even praised by Hall-Dennis?

A possible answer lies within a statement made near the end of the report's précis: “there can be no doubt of Makarenko's own prowess as a teacher, and of his remarkable success in transmuting the worst imaginable juvenile delinquents into self-respecting young men and women." In this, they conform to aspects of the larger liberal political tradition. The idea that all people are born with the capacity to reason, and with a corresponding responsibly to assess their society, is the central building block of liberal thought. This is the "anthropological minimum" of liberalism, as Uday Singh Mehta has argued. ${ }^{75}$ Yet liberal thinkers also have long insisted that this freedom had to be tempered, if not compromised outright, for the sake of social order. For them, society simply could not function otherwise. This comes to the fore in the case of those who do not register as reasonable and responsible individuals - temporarily or permanently. This exclusionary category has, at different times and places, included the insane, criminals, colonial subjects, and children. They would either be educated (in one way or another) to become modal liberal individuals, or be "governed without their consent." ${ }^{76}$ These contradictions often go unnoticed in liberal discourse. As Pierre Bourdieu argues, such myopia is utterly necessary. Without such "blindness," liberalism might fail to function as an ideological system, as those participating in it would run the risk of falling into "bad faith" over such troubling details. ${ }^{77}$

This, in turn, led it to condemn Soviet 'collectivism' on the one hand, while failing to see just how collectivising and coercive its own vision of Ontario education was on the other. A dystopianism that allowed it to advocate humanistic treatment for most students, while condoning pedagogical violence (as Bourdieu would describe it) towards those it considered deviant or delinquent. ${ }^{78}$

This point of view is found throughout Living and Learning as well, and may well bear the imprint of the committee's tour through the Soviet Union. The following passage is but one of many:

We must listen to the young people and give them a chance to speak out. To protest is human, and no society is strong which does not acknowledge the protesting man. It is the exploitation of protest which is dangerous. Therefore we must relate the learning experiences in our schools to the real needs of young people. History has demonstrated too clearly that the lonely ones can lose their weakness when joined together and that they have the potential to find courage and be strong in brutal acts and mob action." 79 
Ultimately, what "Education in the U.S.S.R." offers us is a glimpse into the HallDennis committee's complex utopianism, rather than any 'reality' regarding Soviet education, circa-1966. As the report makes clear, upon arriving in the U.S.S.R., HallDennis was immediately impressed by that state's devotion to educational planning, its interest in pedagogical experimentation, its use of technology in the classroom, and the striking results the system seemed to produce. It was as though the committee had found an educational utopia in the most unlikely of places. And yet, as is often the case with utopias, these impressions soon changed radically. What at first appeared as freedom and forward motion became alienation, stagnation, and oppression. In other words, utopia turned to dystopia. Where "Education in the U.S.S.R." truly surprises, however, is in its adoption of a third position. The committee ended its report by heartily endorsing the coercive pedagogy of Anton Semenovych Makarenko. Thus, what "Education in the U.S.S.R." (and later Living and Learning) demonstrates is that while Hall-Dennis was genuinely committed to individualism in education and democracy in the classroom, it was just as concerned with maintaining order, both within and beyond the schoolhouse. This insight moves us beyond views of the committee that characterize it as simply "child-centered" and "permissive." ${ }^{0}$ Instead, we see that Hall-Dennis' progressive educational utopianism contained a hard, dystopian core: a willingness "to rehabilitate man and condemn him to happiness." 81

\section{Notes}

1 The phrase "Alpha children wear grey" is drawn from Aldous Huxley's Brave New World: A Novel (Harmondsworth: Penguin, 1975), 33.

2 Provincial Committee on Aims and Objectives of Education in the Schools of Ontario, Living and Learning: The Report of the Provincial Committee on Aims and Objectives of Education in the Schools of Ontario (Toronto: Ontario Department of Education, 1968), 4.

3 The Provincial Committee was initially referred to the "Hall committee." It became known as the "Hall-Dennis committee" after Hall suffered a heart attack in late-1966, and Dennis was made co-chair. To keep things simple, I will refer to it as "HallDennis," or simply "the committee' from this point forward.

4 This, of course, points toward the committee's progressive educational orientation. Hall-Dennis' complex relation to the history of progressive education is something I explore in depth in my $\mathrm{PhD}$ dissertation, "Children, Schools, and Utopias: Education and Modernity in Ontario's Long-1960s." Considering that this is a short paper on a focussed topic, I chose to leave this facet of Hall-Dennis' work largely to one side. Key recent works on progressive education in Canada include Paul Axelrod's "Beyond the Progressive Education Debate: A Profile of Toronto Schooling in the 1950s," in Historical Studies in Education/Revue d'histoire de l'éducation17 (2005): 227-241; Robert Stamp, "Growing Up Progressive? Part I: Going to Elementary School in 1940s Ontario," in Historical Studies in Education/Revue d'histoire de l'éducation 17, 1 (2005): 187-198 and "Growing Up Progressive? Part II: Going to High School in 1950s Ontario," in Historical Studies in Education/Revue d'histoire de l'education 17, 2 (2005): 321-331; Amy von Heyking, Creating Citizens: History \& Identity in Alberta's Schools, 1905 to 1980 (Calgary: University of Calgary Press, 2006); and Theodore Michael Christou, Progressive Education: Revisioning and Reframing Ontario's Public Schools, 1919-1942 (Toronto: University of Toronto Press, 2012). 
5 "No Dust Gatherer, This," Globe and Mail, 30 Jun. 2004.

6 R.D. Gidney, From Hope to Harris: The Reshaping of Ontario's Schools (Toronto: University of Toronto Press, 1999), 75.

7 David Churchill, "When Home Became Away: American Expatriates and New Social Movements in Toronto, 1965-1977, (PhD diss. University of Chicago, 2001), 368. For the major historical work on Hall-Dennis, see W.G. Fleming, Ontario's Educative Society, Vol. III: Schools, Pupils, and Teachers (Toronto: University of Toronto Press, 1971), ch. 14; Robert M. Stamp, The Schools of Ontario, 1876-1976 (Toronto: University of Toronto Press, 1982), 216-220; R.D. Gidney, From Hope to Harris: The Reshaping of Ontario's Schools (Toronto: University of Toronto Press, 1999), ch. 4; and Nadeem A. Memon, "Contextualizing Hall-Dennis: The Rise of Progressive Educational Practices in Ontario, 1968-1972" (MA thesis: Ontario Institute for Studies in Education at the University of Toronto, 2005). For an illuminating recent treatment of Living and Learning from a philosophical angle, see Rosa Bruno-Jofré and George Hills, "Changing Visions of Excellence in Ontario School Policy: The Cases of Living and Learning (1968) and For the Love of Learning (1994)," in Educational Theory 61 (2011): 345-369.

8 Daniel T. Rogers, Atlantic Crossings: Social Politics in a Progressive Age (Cambridge and London: Harvard University Press, 1998), 1.

9 Bruce Curtis, "Tocqueville and Lower Canadian Educational Networks," Encounters/ Encuentros/Recontres on Education, Fall (2006): 113-129.

10 Rodgers, Atlantic Crossings, 6-7.

11 Robert M. Stamp, "Government and Education in Post-War Canada, in ed. J. Donald Wilson, Robert M. Stamp, and Louis-Philippe Audet, Canadian Education: A History, (Scarborough: Prentice Hall, 1970), 466-467.

12 Ontario, Legislature of Ontario Debates (7 June 1966), p. 4409 (Hon. William Grenville Davis, Minister of Education/Minister of University Affairs).

13 For an overview of the Cold War as a global event, see Eric Hobsbawm, The Age of Extremes: The Short Twentieth Century, 1914-1991 (London: Abacus, 2004), ch. 8.

14 On Cold War containment in the American context, see Elaine Tyler May, Homeward Bound: American Families in the Cold War Era (New York: Basic Books, 1999), and Andrew Ross, No Respect: Intellectuals \& Popular Culture (New York and London: Routledge, 1989), ch. 2.

15 John L. Rudolph, Scientists in the Classroom: The Cold War Reconstruction of American Science (New York: Palgrave, 2002), 14. See also Christopher P. Loss' Between Citizens and the State: The Politics of American Higher Education in the 20 th Century (Princeton and Oxford: Princeton University Press, 2012), 122-123. Interestingly, Loss argues that the capture and supposed 'brainwashing' of a number of American soldiers during the Korean War was an important step towards a Cold War educational policy. As he has it, the general public was outraged because many of the captured soldiers were high-school drop-outs, insufficiently schooled in the democratic foundations of American society. Thus, they were easily 'broken' by the enemy.

16 Rudolph, Scientists in the Classroom, 75.

17 For a recent book-length treatment on the educational policy response to Sputnik, see Wayne J. Urban, More Than Science and Sputnik: The National Defense Act of 1958 (Tuscaloosa: University of Alabama Press, 2010). On the Cold War and American education more generally, see Andrew Hartman, Education and the Cold War: The Battle for the American School (New York: Palgrave Macmillan, 2008).

18 The classic work on Canada’s Cold War is Reg Whitaker and Gary Marcuse, Cold War Canada: The Making of a National Insecurity State, 1945-1957 (Toronto: University of Toronto Press, 1994). On Canadian/U.S. relations during the war, see Warming Up to the Cold War: Canada and the United States' Cold War of the Willing (Toronto: University 
of the Toronto Press, 2009). Franca Iacovetta's Gatekeepers: Reshaping Immigrant Lives in Cold War Canada (Toronto: Between the Lines, 2006) deals with citizenship education and social policy during this period. Mona Gleason's Normalizing the Ideal: Psychology, Schooling, and the Family in Postwar Canada (Toronto: University of Toronto Press, 1999) contains many valuable insights into the development of Canadian education during the Cold War years.

19 Reg Whitaker and Steve Hewett, Canada and the Cold War (Toronto: Lorimer, 2003), 48.

20 Neatby scathingly criticized what she took to be the anti-democratic policies of socalled progressive educators, who were failing to prepare young citizens to defend liberal-democracy on the global stage. As she wrote in her bestseller, So Little for the Mind: An Indictment of Canadian Education (Toronto: Clarke, Irwin \& Company, 1953), 236: "Without a genuine and personal respect for the integrity of the individual, democracy (for the experts) has resolved itself into a mania for equality and for the so-called 'socialized' existence... As few educators...strive to remedy the real defects in their own education, few are likely to discover how closely their theory and practices are approaching those of the police state. Experts talk constantly of training for leadership, but their whole system is one of conditioning for servitude."

21 George S. Tomkins, A Common Countenance: Stability and Change in the Canadian Curriculum (Vancouver: Pacific Educational Press, 2008), 267.

22 Northrop Frye, "Introduction," in Northrop Frye, ed., Design for Learning: Reports Submitted to the Joint Committee of the Toronto Board of Education and the University of Toronto (Toronto: University of Toronto Press), 7.

23 Lloyd Dennis, The Learning Circus: A Personal Journey Through the Wonderful World of Education (Toronto: Umbrella, 1997), 143; 148.

24 George M. Logan, ed. and trans., Thomas More, Utopia, third ed. (New York and London: Norton, 2011).

25 Lyman Tower Sargent, Utopianism: A Very Short Introduction (Oxford and New York: Oxford University Press, 2010), 2.

26 Barbara Goodwin and Keith Taylor, The Politics of Utopia: A Study of Theory and Practice (Bern: Peter Lang, 2009), 4.

27 Zygmunt Bauman, Socialism: The Active Utopia (London; George Allen \& Unwin, 1976), 13.

28 Michael A. Peters and John Freeman-Moir, "Introducing Edutopias: Concept, Genealogy, Futures," in Michael A. Peters and John Freeman-Moir, eds., Edutopias: New Utopian Thinking in Education (Rotterdam: Sense, 2006), 3; Ivana Milojević, "Hegemonic and Marginalized Educational Utopias in the Contemporary World," in Edutopias., 29.

29 Peters and Freeman-Moir, Ibid.

30 Edward Surtz, The Praise of Pleasure: Philosophy, Education, and Communism in More's Utopia (Cambridge: Harvard University Press, 1957), 78; Milojević, Ibid.

31 Surtz, Ibid, 80.

32 Frédéric Rouvillois, "Utopia and Totalitarianism," in Utopia: The Search for the Ideal Society in the Western World (New York and Oxford: Oxford University Press, 2000), 316.

33 Mark Olssen, Liberalism, Neoliberalism, Social Democracy: Thin Communitarian Perspectives on Political Philosophy and Education (New York and London: Routledge, 2010), ch. 2. Ian McKay, "Canada as a Long Liberal Revolution: On Writing the History of Actually Existing Liberalisms, 1940s-1940s," in Jean-François Constant and Michel Ducharme, eds. Liberalism and Hegemony: Debating the Canadian Liberal Revolution (Toronto: University of Toronto Press, 2009), 362.

34 Bruce Curtis, "After 'Canada': Liberalisms, Social Theory, and Historical Analysis," in Ibid., 181-182. 
35

39 Peters and Freeman-Moir, Ibid., 2.

40 Milojević, Ibid., 21; Hobsbawm, Ibid. 225-400.

41 Doug Owram, Born at the Right Time: A History of the Baby Boom Generation (Toronto: University of Toronto Press, 1999), x.

42 Milojević, Ibid., 27.

43 Michael D. Gordin, Helen Tilley, and Gyan Prakash, "Introduction: Utopia and Dystopia beyond Space and Time," in Michael D. Gordin, Helen Tilley, and Gyan Prakash, eds. Utopia/Dystopia: Conditions of Historical Possibility (Princeton: Princeton University Press, 2010), 1-2.

44 Ibid., 2. On their educational tours, Hall-Dennis found what they considered to be educational chaos in Atlantic Canada and Northern Ontario. From their point of view, the school officials they met in Atlantic Canada seemed completely uninterested in modern education reform - in particular, educational planning. As they wrote: "The delegates were slightly shaken by the casual attitudes displayed by education officials ... A sharp query would produce a shrug and a matter-of-fact 'It just happened this way'. In several instances we got the impression that the main force holding things together was a 'gentleman's agreement'. One official said: 'There is nothing wrong with our system that money couldn't cure'. The Chairman of Newfoundland's Royal Commission on Education complacently contrasted the Maritime attitude with Ontario's anguished soul-searching and endless experimentation. A New Brunswick official commented on the apathy of the New Brunswick populace which apparently 'gives off waves of inertia.' 'Education is in a vacuum', he said. 'And no wonder, said the President of the University of New Brunswick, 'Ontario lures all our best people away.' In Northern Ontario, their impressions were of a system on the brink of no-return. It featured "low morale because of living conditions and associates," "large turnover" of teachers and a general "lack of initiative and training [in] modern methods." Administrators would "look after situations when they arose but were not anxious to look forward to problems," especially the most serious ones. In the case of both Atlantic Canada and Northern Ontario, Hall-Dennis seemed blithely unaware of their own biases and prejudices. "Maritime Tour," n.p., box 23, RG 2-168, Ontario Ministry of Education, Files of the Provincial Committee on Aims and Objectives of Education in the Schools of Ontario, Archives of Ontario (AO); "The Hall Sub-Committee's Northern Investigation,", n.p.; 2, box 23, RG 2-168, Ontario Ministry of Education, Files of the Provincial Committee on Aims and Objectives of Education in the Schools of Ontario, Archives of Ontario (AO).

45 Living and Learning, 9.

46 George Counts, The Challenge of Soviet Education (New York: McGraw-Hill, 1957), 46.

47 Jeremi Suri, Power and Protest: Global Revolution and the Rise of Detente (Cambridge and London: Harvard University Press, 2008), 89.

48 David Engerman, "John Dewey and the Soviet Union," Modern Intellectual History 3 (2006), 39.

49 Ibid., 44; 40-41.

50 Ronald Grigor Suny, The Soviet Experiment: Russia, the USSR, and the Successor States (New York and Oxford: Oxford University Press, 1998), 207. On this early period, see 
Sheila Fitzpatrick, The Commissariat of Enlightenment: Soviet Organization of Education and the Arts under Lunacharsky, October 1917-1921 (Cambridge: Cambridge University Press, 1970).

51 Michael-David Fox, "The Fellow Travellers Revisited: The 'Cultured West' through Soviet Eyes," The Journal of Modern History 75 (75), no. 2 (2003), 300. The classic account is David Caute, The Fellow-Travellers: A Postscript to the Enlightenment (London: Weidenfeld \& Nicolson, 1973).

52 Sylvia R. Margulies, The Pilgrimage to Russia: The Soviet Union and the Treatment of Foreigners, 1924-1937 (Madison, Milwaukee, and London; The University of Wisconsin Press, 1968), 11-12.

53 Engerman, "John Dewey," 43.

54 Ibid., 48.

55 Suny, Soviet Experiment, 409.

56 Ibid.

57 "Education in the U.S.S.R.," 1, box 23, RG 2-168, Ontario Ministry of Education, Files of the Provincial Committee on Aims and Objectives of Education in the Schools of Ontario, Archives of Ontario (AO).

58 Ibid., 8.

59 Ibid., 5.

60 Ibid., 6.

61 This theory was introduced in Bruner's The Process of Education (Cambridge: Harvard University Press, 1963). For its Canadian impact, see Tompkins, Stability and Change, 265-268, and Frye, ed. Design for Learning, which was an attempt to apply it to the Ontario curriculum.

62 "Education in the U.S.S.R.," 6.

63 Ibid., 7.

64 Ibid., 6.

65 Ibid., 9.

66 Ibid., 10.

67 Ibid., 4.

68 Ibid.

69 Ibid., 13.

70 Ibid., 14.

71 James Bowen, Makarenko and the Years of Experiment (Madison: University of Wisconsin Press, 1965), 121-122.

72 Ibid., 39.

73 Ibid., 77

74 Ibid., 75. Makarenko himself relates such an incident in his most famous work, The Road to Life (An Epic of Education), Part One Ivy and Tatiana Litvinov, trans., (Moscow: Foreign Languages Publishing House, 1951), 44; 48: "And then, one day, the storm broke. I suddenly lost my footing on the tight rope of pedagogical practice. One wintry morning I asked Zadorov to chop some wood for the kitchen stove, receiving the usual cheerfully insolent reply: 'Do it thyself! ... It was the first time any of the boys addressed me with the familiar 'thou.' Desperate with rage and indignation, driven to utter exasperation by the experiences of the previous months, I raised my hand and dealt Zadorov a blow full in the face. I hit him so hard that he lost his balance and fell against the stove. Again I struck him, seizing him by the collar and actually lifting him off his feet. And then I struck him a third time.” Later, in reflecting on his actions, Makarenko wrote: "The incident with Zadorov proved to be a turning point in discipline. I have to admit that I was beset by no qualms of conscience. Very well-I had struck one of my pupils. Keenly as I felt the pedagogical impropriety, the illegality of my action, at the same time I realized that the purity of our pedagogical conscience 
would have to be subordinated to the immediate task before me. I firmly decided to be a dictator if other methods failed." For a puzzling defense of Makarenko's methods, see Bob Davis, Teaching Tough Kids: What We Can Learn from Five Provocative Educators (Ottawa: Canadian Centre for Policy Alternatives, 2004), ch. 2.

75 Uday Singh Mehta, Liberalism and Empire: A Study in Nineteenth-Century British Liberal Thought (Chicago and London: University of Chicago Press, 1999), 52-53. On the development of the 'capacity to judge' in English Canada, see Jeffrey L. McNairn, The Capacity to Judge; Public Opinion and Deliberative Democracy in Upper Canada, 17911854 (Toronto: University of Toronto Press, 2000).

76 Mehta, Liberalism and Empire, 48-49.

77 Pierre Bourdieu, Political Interventions: Social Science and Political Action (London and New York: Verso, 2008), 67.

78 On 'pedagogical violence,' see Pierre Bourdieu and Jean-Claude Passeron, Reproduction in Education, Society and Culture, Richard Nice, trans. (London, Thousand Oaks, and New Delhi: Sage, 2000).

79 Living and Learning, 45.

80 James Daly, Education or Molasses: A Critical Look at the Hall-Dennis Report (Ancaster: Cromlech, 1969), 8.

81 Rouvillois, Ibid., 316. 